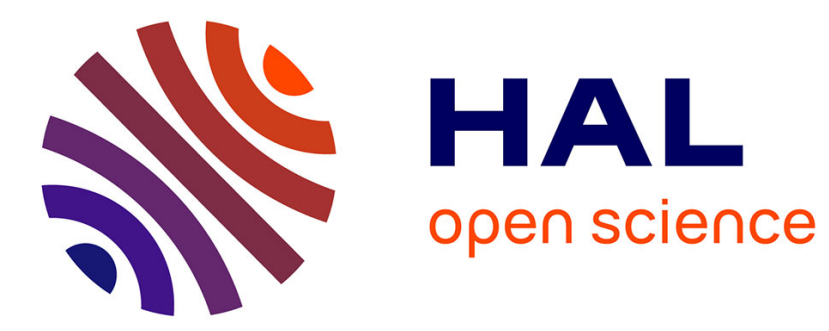

\title{
Seasonal variation in mobbing behaviour of passerine birds
}

Mylène Dutour, Marion Cordonnier, Jean-Paul Léna, Thierry Lengagne

\section{To cite this version:}

Mylène Dutour, Marion Cordonnier, Jean-Paul Léna, Thierry Lengagne. Seasonal variation in mobbing behaviour of passerine birds. Wilson journal of ornithology, 2019, 160 (2), pp.509-514. 10.1007/s10336-019-01630-5 . hal-02155214

\section{HAL Id: hal-02155214 \\ https://univ-lyon1.hal.science/hal-02155214}

Submitted on 5 Jan 2021

HAL is a multi-disciplinary open access archive for the deposit and dissemination of scientific research documents, whether they are published or not. The documents may come from teaching and research institutions in France or abroad, or from public or private research centers.
L'archive ouverte pluridisciplinaire HAL, est destinée au dépôt et à la diffusion de documents scientifiques de niveau recherche, publiés ou non, émanant des établissements d'enseignement et de recherche français ou étrangers, des laboratoires publics ou privés. 


\section{Seasonal variation in mobbing behaviour of passerine birds}

2 Mylène Dutour • Marion Cordonnier • Jean-Paul Léna • Thierry Lengagne

3 Université Lyon, Université Claude Bernard Lyon 1, CNRS, ENTPE, UMR5023 LEHNA, F-

4 69622, Villeurbanne, France

$5 \quad$ Corresponding author: Mylène Dutour, email: mylene.dutour@hotmail.com telephone number: +336.72 .18 .27 .62 fax number: +334.72 .43 .11 .41$

\section{Abstract}

When they detect a predator, many birds exhibit mobbing behaviour and produce mobbing calls that quickly draw other prey against the predator. Such antipredator strategy often involves several species and therefore implies heterospecific communication. As fledging and nestling stages could be particularly targeted by predators, a high mobbing intensity is to be expected during the breeding season. While recognizing other species' mobbing calls is critical to setting up this behaviour, to date, we have no information about the perception of these calls with regard to t season. Here, we used playbacks of mobbing calls to study the variation in response of the Great Tit (Parus major) and the Blue Tit (Cyanistes caeruleus) exposed to the mobbing calls of two heterospecific species, the Eurasian Nuthatch (Sitta europaea), and the Eurasian Wren (Troglodytes troglodytes). To investigate mobbing response seasonality, we conducted playback experiments during spring (breeding season) and autumn (non-breeding season). Contrary to most previous studies, we found that mobbing intensity was greater in autumn than in spring. Additionally, although neither Nuthatch nor Wren is related to the Tit family, we found that both Tit species responded more to the former than the latter species. At the heterospecific communication level, this study demonstrates a previously unsuspected level of complexity in the use of mobbing calls. 
25 Keywords Bird calls - Interspecific recognition - Interspecific communication $\bullet$ Mobbing • Passerines • Paridae

27

Acknowledgments This study was supported by French Ministry of Research and Higher Education funding (to M.D. PhD grants 2015-2018). It was conducted with the approval of the Prefecture du Rhône, in accordance with the current laws in France. We thank David Wheatcroft for providing the wren mobbing call data. We thank two anonymous referees whose comments helped us greatly improve the quality of this article. The datasets generated during and/or analysed during the current study are available from the corresponding author following a reasonable request. 


\section{Introduction}

The key role of anti-predation defences in predator-prey relationships has been studied for many years, particularly in birds. When birds encounter predators, many species are likely to emit alarm calls. These alarm calls may be used to alert conspecifics of potential danger (Weary and Kramer 1995) or recruit nearby individuals for mobbing defence against the predator (Curio et al. 1978). Mobbing calls typically incite other potential prey to fly towards the caller and the predator. This mobbing behaviour may have several different functions and one of the most important is probably to drive the predator away from the vicinity (Pettifor 1990; Flasskamp 1994). The greater the number of mobbers, the greater the chances of driving away a predator (Picman et al. 1988; Krams et al. 2009). However, mobbing entails a real risk to the prey involved, owing to its proximity to the predator (Denson 1979; Curio and Regelmann 1986). Preys adjust the strength of their mobbing behaviour according to the perceived risk associated with the predator's threat level (Billings et al. 2015; Dutour et al. 2016; Dutour et al. 2017a). Other factors, including the proximity of the predator (Creswell 1993; Kleindorfer et al. 2005), its posture (Hamerstrom 1957; Coss and Ramakrishnan 2000) and its behaviour (Lind et al. 2005; Nolen and Lucas 2009) are also involved in explaining the strength of the mobbing. Among these, seasonality is a probably an important factor to explain mobbing behaviour intensity.

Although mobbing can occur in the autumn and winter months, many studies have shown that the mobbing response to predators is higher during the breeding season (Altmann 1956; Shedd 1982; Shedd 1983; Krams and Krama 2002). Authors have suggested that the willingness of birds to mob during the breeding season probably stems from at least two factors: (1) birds are territorial at this time and lack the option of easy relocation away from predators on their territories, and (2) birds are likely to have eggs or young more vulnerable to the predator (Shedd 1982). Some studies have also documented a temporal intensification in 
mobbing behaviour during the breeding cycle. For example, parents increase the strength of this mobbing during the breeding cycle, whereas mobbing is rarely performed during the nest building or egg-laying phase (Montgomerie and Weatherhead 1988; Redondo 1989). Finally, an individual's response intensity to the mobbing playback is a significant predictor of reproductive success (Doran et al. 2005), although one study showed that mobbing calls can increase the rates of nest predation and lower breeding success (Krams et al. 2007). However, Dutour et al. (2017a) observed a reverse pattern when studying responses in birds communities to the Eurasian Pygmy Owl (Glaucidium passerinum), with a higher response rate in autumn than during the breeding season. Because the study of Dutour et al. (2017a) focused on a global response from all the species predated by the Pygmy Owl, any comparison between seasons on a species scale would be impossible. In addition, with such an experimental design it is not possible to discriminate between responses emitted towards predators and responses to interspecific mobbing calls. To our knowledge, the mobbing behaviour set up in response to interspecific calls has never been studied across seasons. Hence, there is a need for a pairwise comparison of caller-receiver species to explain their behavioural responses during different seasons.

Like other members of the Paridae family, the great tit (Parus major) and the blue tit (Cyanistes caeruleus) are highly vigilant and aggressive during mobbing events: they form mixed-species flocks and mob together (Dutour et al. 2017a). These interspecific flocks can constitute facilitators of mobbing (Goodale and Kotagama 2005; Nolen and Lucas 2009). Here, we address one previously unexamined aspect of the mobbing behaviour of passerine birds. We examine to what extent responses to interspecific mobbing calls vary according to the season. We investigate the variation in response of the Great Tit and the Blue Tit exposed to the mobbing calls of the Eurasian Nuthatch (Sitta europaea) and the Eurasian Wren 
(Troglodytes troglodytes). We predict that the mobbing response should be more intense during the autumn than during spring.

\section{Methods}

\section{Species and sites studied}

The study was conducted in large mixed deciduous-coniferous forests near Lyon in the Rhône-Alpes region (France; 458’N, $4^{\circ} 52^{\prime} \mathrm{E}$ ). To ensure the independence of experimental testing (no bird was tested twice during our study), playback sites were separated by more than $100 \mathrm{~m}$ and we never came back a second time to the same place. In addition, we avoided any temporal effect during our experiments by evenly distributing the playbacks of the different species across the study period. All tests were conducted in the breeding season (April-Jun 2016) and in the autumn (September-October 2016). Tests involved 140 different individuals (the detailed number of tests conducted for each combination is presented in Table $1)$.

\section{Playback Experiments}

Once a target bird was identified, we placed the loudspeaker used to broadcast the acoustic signal $30 \mathrm{~m}$ away from the bird at the base of a tree. We performed our playback experiments only when no other passerines were observed near the targeted individual, to be sure that the response of the tested bird was due to our playback rather than to the behaviour of other passerines. All tests, where an untargeted bird started to mob before the targeted bird, were discarded from the dataset. Once the loudspeaker was positioned, two observers with binoculars stood opposite each other at vantage points $15 \mathrm{~m}$ away from the loudspeaker to observe bird response during the test. All tests were divided into a 1 min baseline of silence, followed by 1 min of signal playback. We found no evidence that our presence disturbed the 
behaviour of the target bird before the playback emission. During the playback, we considered that the target bird responded positively to our test if it approached within a $15 \mathrm{~m}$ radius of the loudspeaker (see Dutour et al. 2017b for more details).

\section{Choice of experimental stimuli and playback materials}

The mobbing calls produced by Wren and Nuthatch in response to a pygmy owl or uploaded from Xeno Canto (XC file hereafter) online database were played with a Shopinnov 20W loudspeaker (frequency response $100 \mathrm{~Hz}-15 \mathrm{kHz}$ ). To limit pseudo replication (Hurlbert 1984; Kroodsma 2001), we used mobbing calls from 5 different individuals for the Wren (XC252499) and we used two soundtracks recorded in two populations for the Nuthatch (Germany XC252502 and Sweden XC28224).

\section{Statistical analysis}

Analyses were done using R v.2.15.1 software (R Development Core Team 2012). We used generalised linear mixed models (GLMM) to investigate the variation in mobbing propensity (i.e. speaker approach) among the receiver species (i.e. Great Tit or Blue Tit) and according to the mobbing stimuli broadcast (i.e. mobbing calls of Nuthatch and Wren) and the season (breeding season and autumn). More specifically, the individual binary response (mobbing response $=1$; no mobbing response $=0$ ) was introduced as dependent variable using a logit link and a binomial distribution for the error term, and the season, the receiver species, the mobbing stimuli and their interactive effects were introduced as explanatory terms in the fixed part of the model. As different playback soundtracks were used for each receiver species, soundtracks were introduced in the model as random effects. We also performed a model for each receiver species to investigate the variation in mobbing propensity according to the season and the mobbing stimuli. 


\section{Results}

138 Our analyses showed that the season, the receiver species and mobbing stimuli have a 139 significant additive effect on the proportion of individuals which exhibited mobbing 140 behaviour (Table 2; Fig. 1). Blue Tits responded more strongly than Great Tits $(p=0.033)$. In 141 Great Tits, both mobbing stimuli and season had a significant additive effects on the proportion of individuals that exhibited mobbing behaviour (season effect: $\chi_{1}^{2}=3.527, p=$

1430.060 ; mobbing stimuli effect: $\left.\chi_{1}^{2}=5.10 ; p=0.024\right)$. Great Tits mobbed 1.8 times more 144 during autumn than they did during the breeding season. In response to Nuthatch calls, Great 145 Tits were more likely to approach within $15 \mathrm{~m}$ of the loudspeaker than in response to Wren 146 calls. Concerning the Blue Tits, we obtained the same result (season effect: $\chi_{1}^{2}=5.36, p=$ 147 0.021; mobbing stimuli effect: $\chi_{1}^{2}=5.12, p=0.023$ ): individuals mobbed 1.7 times more 148 during the autumn than they did during the breeding season and were more prone to respond 149 to Nuthatch calls than to Wren calls.

\section{Discussion}

Our playback experiments indicated that mobbing intensity was significantly greater in autumn than in the breeding season, whatever the receiver species or mobbing stimuli used and despite the fact that we may have tested juveniles (3-4 months old) with lesser experience on mixed-flocks and potentially showing weaker response. This result does not agree with most of the previous studies, which suggested increased mobbing activity during the breeding season (e.g., Altmann 1956; Shedd 1982; Shedd 1983; Krams and Krama 2002). However, those studies examined mobbing behaviour in response to conspecific mobbing calls or to predator playbacks but not against interspecific mobbing calls (but see Tremblay and St Clair 2009). Nonetheless, these results confirm, on the species scale, the results obtained in a 
previous study conducted on the community scale (Dutour et al. 2017a). Increased mobbing activity during autumn could be explained by a seasonal variation in predator diet, as predation pressure on passerine birds is probably different across seasons (Dutour et al. 2017a). In the case where birds make up a large share of the predator's diet year round, vigorously attacking them at any time may make evolutionary sense (Cully and Ligon 1986; Nijman 2004; Chiver et al. 2017; Dutour et al. 2017a). In our case, a higher predation pressure in autumn could then explain more intense mobbing behaviours at this time. In addition, contrary to the breeding season, where mobbing behaviour is constrained by territorial boundaries (Betts et al. 2005), during the non-breeding season mobbing could occur in areas outside the territory, increasing opportunities to respond to mobbing calls. Alternatively, higher mobbing intensity during autumn could be explained by migratory patterns. If the birds tested are migratory birds, they have less opportunity to meet local predators, possibly leading Tits to respond to the mobbing calls of resident species in order to gather information (Nocera et al. 2008). Ultimately, increased mobbing activity during autumn could be related to variations in sensitivity of the receiver (Lucas et al. 2002; Lucas et al. 2007). During the breeding season, Tits spend time with their conspecifics (mate and nestlings), whereas they form mixed-species flocks during the non-breeding season. We could suggest that species are more sensitive (i) to conspecific mobbing calls during the breeding season and (ii) to heterospecific mobbing calls during the non breeding season. During the breeding season, a targeted individual has an interest in responding to conspecific mobbing calls because the probability that mobbing calls are emitted by its mate are high, even though this strategy presumes individual recognition (Kennedy et al. 2009; Wheatcroft and Price 2008; McDonald 2012). Furthermore, for conspecifics, mobbing could play important indirect roles during the breeding season. For example, da Cunha et al. (2017) suggest that males may use mobbing to display their phenotypic quality to females. In this case, predator mobbing could be seen as a 
way to influence sexual selection. Conversely, during the autumn and winter months, some passerine birds conduct the majority of their daily activities with mixed-species flocks (Ekman 1989). As birds often respond "by contagion" to the reactions of other birds, it is possible that during this period a higher number of prey species increase the propensity of birds to react and thus increase the strength of the mobbing, as shown by Sieving et al. (2004). Thus, in the non-breeding season, all these factors together can trigger a strong response from passerines to the mobbing calls of other species.

Our results indicated that Great and Blue Tits responded more strongly to the calls of Nuthatch and much less to those of Wren. The similarity in response of Blue Tits and Great Tits to both Nuthatch and Wren calls suggests that they may use these signals in an analogous manner. Nuthatch is a passerine that may occur in mixed flocks with Tits during the nonbreeding season (Hinde 1952), whereas the Eurasian Wren is a species with which they rarely co-exist. Thus, Tits may have opportunities to learn to associate the heterospecific mobbing calls of Nuthatches with predatory threats, and this may contribute to the rapid spread of antipredator behaviour within a bird community (Wheatcroft and Price 2013; Magrath et al. 2015; Suzuki 2016). Our results go beyond simple learning, as they suggest that previous exposure and learning maintain heterospecific responses (Wheatcroft and Price 2013), in addition to innate processes (Randler 2012; Dutour et al. 2017b). To test the role of learning between species, we could have tested juveniles with less experience of mixed-flocks in Autumn. Juveniles should respond less than adults. Other hypotheses could be advanced to explain an increasing mobbing response to Nuthatch: Tits are very similar in size to Nuthatches, occupy many of the same habitats, and are therefore attacked by most of the same predators. Furthermore, it has been found that the White-Breasted Nuthatch (Sitta carolinensis), a close relative of the Eurasian Nuthatch, has (i) a greater ability to detect the predator playback (Lucas et al. 2002; Lucas et al. 2007) and (ii) a greater tendency to mob before other species 
211 (Nolen and Lucas 2009). In our case, Eurasian Nuthatch may have played a key role in the initiation of mobbing behaviour and that can be beneficial in responding to its mobbing calls. Tits make complex antipredator responses depending on the mobber's identity and their ecological relations. Recognizing other species' mobbing calls is critical for the efficiency of the antipredator behaviour. Previous studies suggest that Red-Breasted Nuthatches (Sitta canadensis) discriminate between subtle differences in Black-Capped Chickadees (Poecile atricapillus) alarm calls that contain information about the size of potential predators (Templeton and Greene 2005; Templeton and Greene 2007). A next step is to study how passerine birds encode information about predator threat in their mobbing calls (see Carlson et al. 2017 for Paridae) and how this information is used by heterospecifics. mobbing is a complex antipredator strategy, and many parameters, such as prevalence in flocks, similarity of mobbing calls or learning process among species sharing the same habitat, may influence the expression of this behaviour. Further research identifying mobbing and non-mobbing species would provide information on species interdependence and avian community organization.

\section{References}

Altmann SA (1956) Avian mobbing behavior and predator recognition. Condor 58:241-253

Billings AC, Greene E, Lucia Jensen SM (2015) Are chickadees good listeners? Antipredator 
Carlson NV, Healy SD, Templeton CN (2017) A comparative study of how British tits encode predator threat in their mobbing calls. Anim Behav 125:77-92

Chiver I, Jaramillo CA, Morton ES (2017) Mobbing behavior and fatal attacks on snakes by Fasciated Antshrikes (Cymbilaimus lineatus). J Ornithol 158:935-942

Coss RG, Ramakrishnan U (2000) Perceptual aspects of leopard recognition by wild bonnet macaques (Macaca radiata). Behaviour 137:315-335

Creswell W (1993) Escape responses by redshanks, Tringa totanus, on attack by avian predators. Anim Behav 46:609-611

Cully JF, Ligon JD (1986) Seasonality of mobbing intensity in the Pinyon Jay. Ethology $71: 333-339$

Curio E, Ernst U, Vieth W (1978) The adaptive significance of avian mobbing. Ethology 48:184-202

Curio E, Regelmann K (1986) Predator harassment implies a real deadly risk: a reply to Hennessy. Ethology 72:75-78

da Cunha FCR, Fontenelle JCR, Griesser M (2017) The presence of conspecific females influences male-mobbing behavior. Behav Ecol Sociobiol 71:52

Denson RD (1979) Owl predation on a mobbing crow. Wilson Bull 91:133-133

Doran PJ, Gulezian PZ, Betts MG (2005) A test of the mobbing playback method for estimating bird reproductive success. J Field Ornithol 76:227-233

Dutour M, Lena JP, Lengagne T (2017a) Mobbing behaviour in a passerine community increases with prevalence in predator diet. Ibis 159:324-330

Dutour M, Léna JP, Lengagne T (2017b) Mobbing calls: a signal transcending species boundaries. Anim Behav 131:3-11

Dutour M, Lena JP, Lengagne T (2016) Mobbing behaviour varies according to predator dangerousness and occurrence. Anim Behav 119:119-124 
Ekman J (1989) Ecology of non-breeding social-systems of Parus. Wilson Bull 101:263-288

Flasskamp A (1994) The adaptive significance of avian mobbing. V. An experimental test of the 'move on' hypothesis. Ethology 96:322-333

Goodale E, Kotagama SW (2005) Alarm calling in Sri Lankan mixed-species bird flocks. Auk $122: 108-120$

Hamerstrom F (1957) The influence of a hawk's appetite on mobbing. Condor 59:192-194

Hinde RA (1952) The behaviour of the great tit (Parus major) and some other related species. Behaviour Suppl. II 1-153

Hurlbert SH (1984) Pseudoreplication and the design of ecological field experiments. Ecol Monog 54:187-211

Kennedy RA, Evans CS, McDonald PG (2009) Individual distinctiveness in the mobbing call of a cooperative bird, the noisy miner Manorina melanocephala. J Avian Biol 40:481490

Kleindorfer S, Fessl B, Hoi H (2005) Avian nest defence behaviour: assessment in relation to predator distance and type, and nest height. Anim Behav 69:307-313

Krams I, Krama T, Igaune K, Mänd R (2007) Long-lasting mobbing of the pied flycatcher increases the risk of nest predation. Behav Ecol 18:1082-1084

Krams I, Berzins A, Krama T (2009) Group effect in nest defence behaviour of breeding pied flycatchers, Ficedula hypoleuca. Anim Behav 77:513-517

Krams I, Krama T (2002) Interspecific reciprocity explains mobbing behaviour of the breeding chaffinches, Fringilla coelebs. Proc R Soc B 269:2345-2350

Kroodsma DE, Byers BE, Goodale E, Johnson S, Liu WC (2001) Pseudoreplication in playback experiments, revisited a decade later. Anim Behav 61:1029-1033

Lind L, Jöngren F, Nilsson J, Alm DS, Strandmark A (2005) Information, predation risk and foraging decisions during mobbing in Great Tits Parus major. Ornis Fenn 82:89-96 
Lucas J, Freeberg T, Krishnan A, Long G (2002) A comparative study of avian auditory brainstem responses: correlations with phylogeny and vocal complexity, and seasonal effects. J Comp Physiol A 188:981-992

Lucas JR, Freeberg TM, Long GR, Krishnan A (2007) Seasonal variation in avian auditory evoked responses to tones: a comparative analysis of Carolina chickadees, tufted titmice, and white-breasted nuthatches. J Comp Physiol A 193:201-215

Magrath RD, Haff TM, McLachlan JR, Igic B (2015) Wild birds learn to eavesdrop on heterospecific alarm calls. Curr Biol 25:2047-2050

McDonald PG (2012) Cooperative bird differentiates between the calls of different individuals, even when vocalizations were from completely unfamiliar individuals. Biol Letters 8:365-368

Montgomerie RD, Weatherhead PJ (1988) Risk and rewards of nest defence by parent birds. Q Rev Biol 63:167-187

Nijman V (2004) Seasonal variation in naturally occurring mobbing behaviour of Drongos (Dicruridae) towards two avian predators. Ethol Ecol Evol 16:25-32

Nocera JJ, Taylor PD, Ratcliffe LM (2008) Inspection of mob-calls as sources of predator information: response of migrant and resident birds in the Neotropics. Behav Ecol Sociobiol 62:1769-1777

Nolen MT, Lucas JR (2009) Asymmetries in mobbing behaviour and correlated intensity during predator mobbing by nuthatches, chickadees and titmice. Anim Behav 77: $1137-1146$

Pettifor RA (1990) The effects of avian mobbing on a potential predator, the European kestrel, Falco tinnunculus. Anim Behav 39:821-827

Picman J, Leonard M, Horn A (1988) Antipredation role of clumped nesting by marsh-nesting red-winged blackbirds. Behav Ecol Sociobiol 22:9-15 
Randler C (2012) A possible phylogenetically conserved urgency response of great tits (Parus major) towards allopatric mobbing calls. Behav Ecol Sociobiol 66:675-681

Redondo T (1989) Avian nest defence: theoretical models and evidence. Behaviour 111:161195

Shedd DH (1982) Seasonal variation and function of mobbing and related antipredator behaviors of the American Robin (Turdus migratorius). Auk 99:342-346

Shedd DH (1983) Seasonal variation in mobbing intensity in the Black-capped Chickadee. Wilson Bull 95:343-348

Sieving KE, Contreras TA, Maute KL (2004) Heterospecific facilitation of forest-boundary crossing by mobbing understory birds in north-central Florida. Auk 121:738-751

Suzuki TN (2016) Referential calls coordinate multi-species mobbing in a forest bird community. J Ethol 34:79-84

Templeton CN, Greene E (2007) Nuthatches eavesdrop on variations in heterospecific Chickadee mobbing alarm calls. Proc Natl Acad Sci USA 104:5479-5482

Templeton CN, Greene E, Davis K (2005) Allometry of alarm calls: black-capped chickadees encode information about predator size. Science 308:1934-1937

Tremblay MA, St Clair CC (2009) Factors affecting the permeability of transportation and riparian corridors to the movements of songbirds in an urban landscape. J Applied Ecol 46: 1314-1322

Wheatcroft D, Price TD (2008) Reciprocal cooperation in avian mobbing: playing nice pays. T Ecol Evol 23:416-419

Wheatcroft D, Price TD (2013) Learning and signal copying facilitate communication among bird species. Proc R Soc B 280:20123070

Weary DM, Kramer DL (1995) Response of eastern chipmunks to conspecific alarm calls. Anim Behav 49:81-93 
336

337 Fig. 1 Percentage of trials in which Great Tits and Blue Tits approached within $15 \mathrm{~m}$ of the

338 loudspeaker during the presentations of mobbing calls of a Wren (grey) and a Nuthatch

339 (black) in the breeding season and in autumn.

340 
341 Table 1 Details of the number of tests conducted for each combination in this study $(n=140)$

\section{Playbacks}

Nuthatch Wren

\begin{tabular}{cccccc} 
& & Breeding season & Autumn & Breeding season & Autumn \\
\hline $\begin{array}{c}\text { Tested } \\
\text { species }\end{array}$ & Blue Tit & 15 & 21 & 15 & 15 \\
& Great Tit & 15 & 21 & 18 & 20 \\
\hline
\end{tabular}

342

343 Table 2 Generalised linear mixed model type II Wald Chi-square results

\begin{tabular}{lcc}
\hline $\begin{array}{l}\text { Explanatory terms in the } \\
\text { fixed part of the models }\end{array}$ & $\chi 2$ & $p$ \\
\hline season & $9.65^{\mathrm{a}}$ & 0.002 \\
receiver species & $4.521^{\mathrm{a}}$ & 0.033 \\
mobbing stimuli & $9.236^{\mathrm{a}}$ & 0.002 \\
season*receiver species & $0.229^{\mathrm{a}}$ & 0.632 \\
season*mobbing stimuli & $0.036^{\mathrm{a}}$ & 0.849 \\
receiver species*mobbing stimuli & $0.011^{\mathrm{a}}$ & 0.915 \\
season*receiver species*mobbing stimuli & $0.593^{\mathrm{a}}$ & 0.441 \\
\hline
\end{tabular}

$344{ }^{\mathrm{a}} d f=1$ 